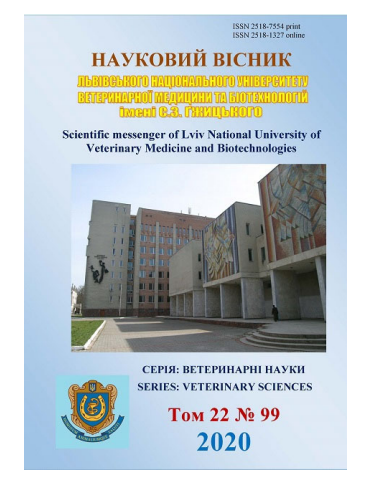

\author{
Науковий вісник Дьвівського національного університету \\ ветеринарної медицини та біотехнодогій імені С.3. Гжицыкого. \\ Серія: Ветеринарні науки \\ Scientific Messenger of Lviv National University \\ of Veterinary Medicine and Biotechnologies. \\ Series: Veterinary sciences
}

\title{
Clinical signs of hypothyroidism in domestic dogs
}

\author{
T. P. Lokes-Krupka ${ }^{1}$, M. I. Tsvilichovsky ${ }^{2}$, S. M. Zarytskyi ${ }^{1}$ \\ ${ }^{1}$ Poltava State Agrarian Academy, Poltava, Ukraine \\ ${ }^{2}$ National University of Life and Environmental Sciences of Ukraine, Kyiv, Ukraine
}

Article info

Received 08.09.2020

Received in revised form 07.10 .2020

Accepted 08.10.2020

Poltava State Agrarian Academy, Skovorody Str., 1/3, Poltava, 36003, Ukraine.

Tel.: +38-050-21-47-056

E-mail:terra_vet@ukr.net

National University of Life and Environmental Sciences of

Ukraine, Heroiv Oborony Str., 15, Kyiv, 03041, Ukraine.
Lokes-Krupka, T. P., Tsvilichovsky, M. I., \& Zarytskyi, S. M. (2020). Clinical signs of hypothyroidism in domestic dogs. Scientific Messenger of Lviv National University of Veterinary Medicine and Biotechnologies. Series: Veterinary sciences, 22(99), 80-83. doi: 10.32718/nvlvet9913

The research was conducted during 2016-2019 on the basis of veterinary clinics in Poltava - veterinary clinic at the Department of Therapy named after Professor P.Lokes of Poltava State Agrarian Academy, "Vet Line", "Vet Comfort" and the laboratory of the Department of Therapy named after Professor P. I. Lokes of Poltava State Agrarian Academy. During the research we studied 11 dogs, which were diagnosed with hypothyroidism. The animals belonged to different breeds, had different sexes (6 females and 5 males) and age. For control we took 15 dogs without visible signs of any pathology. We compared the breed susceptibility of dogs with hypothyroidism and dogs with alimentary obesity. Thus, we found that most breeds are common to animals in both pathologies. However, in our sample for hypothyroidism there was no such breed as a pug, and outbred individuals, which accounted for a significant percentage of dogs with alimentary obesity. One of the most common clinical symptom is the presence of symmetrical alopecia on the sides on the background of dull and disheveled hair (90.9\%). Mucosal anemia was observed in a significant proportion of animals $(81.8 \%)$. The symptom of bradycardia and shortness of breath during exercise is observed in $72.7 \%$ of experimental animals, which indicates the development of pathological changes in the cardiovascular system. It was found that all animals showed depression, weakness and fatigue $(100.0 \%)$. Polydipsia and hypothermia were much less common in $45.5 \%$ of dogs, and corneal dystrophy in $36.4 \%$ of cases. The last clinical manifestation occurred in animals with the most severe pathology. According to the literature, it is known that hypothyroidism in dogs is often a symptom of obesity. According to our data, obesity (overweight) was registered in $63.6 \%$ of experimental animals. With the diagnosis of "hypothyroidism" in dogs, we identified two experimental groups: 1 - animals with normal fatness; 2nd with a clinical symptom of obesity. We can note a significant increase in adipose tissue in dogs with hypothyroidism of the 2nd experimental group $(45.1 \pm 1.70 \%)$, which indicates the presence of endocrine obesity, as evidenced by visual assessment of fatness $(4.7 \pm 0.18$ points). Such changes develop due to insufficient production of thyroid hormones. The latter play an important role in regulating metabolism in the body. Due to their deficiency, the metabolism in animals slows down and, as a result, there is a risk of obesity.

Key words: symptoms, hypothyroidism, endocrine obesity, overweight, dogs.

\section{Клінічні ознаки гіпотиреозу у свійських собак}

\author{
Т. П. Локес-Крупка ${ }^{1}$, М. І. Цвіліховський ${ }^{2}$, С. М. Зарицький ${ }^{1}$ \\ ${ }^{1}$ Полтавська державна аграрна академія, м. Полтава, Україна \\ ${ }^{2}$ Національний університет біоресурсів і природокористування Украӥни, м. Київ, Украӥна
}

\footnotetext{
Дослідження проводили впродовж 2016-2019 років на базі клінік ветеринарної медицини м. Полтава - клініки ветеринарної медицини при кафедрі терапї імені професора П. І. Локеса Полтавської державної аграрної академї, “Vеt Line”, “Vеt Cотfort”, та лабораторії кафедри терапії імені професора П. І. Локеса Полтавської державної аграрної академії. За час виконання роботи нами було досліджено 11 свійських собак, в яких за комплексного обстеження встановлений діагноз гіпотиреоз. Тварини належали до різних порід, мали різну статеву (6 самиць і 5 самиів) і вікову приналежність. За контроль нами були взяті 15 свійських собак
} 
без видимих ознак будь-якої патології. Нами проведено порівняння порідної схильності собак, які страждають на гіпотиреоз та собак із аліментарним ожирінням. В нашій вибориі за гіпотиреозу була відсутня така порода свійського собаки як мопс, та безпородні особини, щзо складали значний відсоток собак з аліментарним ожирінням. Одним з клінічних симптомів, який найчастіше реєструвався, є наявність симетричних алопечій на боках на тлі тьмяного та скуйовдженого шерстного покриву (90,9 \%). У значної частини тварин спостерігалась анемічність слизових оболонок (81,8\%). Симптом брадикардії та задимки під час фізичного навантаження відмічається у 72,7\% дослідних тварин, шуо свідчить про розвиток патологічних змін серцево-судинної системи. За даними літератури відомо, щзо за гіпотиреозу в собак часто спостерігається симптом ожиріння. За нашими даними ожиріння (надмірну вгодованість) реєстрували у 63,6 \% хворих тварин. Встановлено, щуо у всіх тварин відмічали пригнічення, слабкість та швидку втомлюваність (100,0 \%). Полідипсія і гіпотермія виявлялися значно рідше - у 45,5 \% собак, а дистрофія рогівки - у 36,4 \% випадків. За встановленого діагнозу “гіпотиреоз” у свійських собак нами були виділені дві дослідні групи: 1-а тварини з нормальною вгодованістю; 2-a - із клінічним симптомом ожиріння. Базуючись на даних таблиці можна відмітити значне зростання вмісту жирової тканини у собак за гіпотиреозу 2-ї дослідної групи (45,1 $\pm 1,70 \%$ \%), ияо свідчить на наявність ендокринного ожиріння, щзо підтверджується візуальною оцінкою вгодованості (4,7 \pm 0,18 балів). Такі зміни розвиваються внаслідок недостатності вироблення гормонів щитоподібної залози. Останні відіграють важливу роль у регулюванні обміну речовин в організмі. За їх дефіциту обмін речовин в організмі тварин сповільнюється $i$, в результаті, існує ризик розвитку ожиріння.

Ключові слова: симптоми, гіпотиреоз, ендокринне ожиріння, надмірна вгодованість, собаки.

\section{Ветуп}

Існує ряд ендокринних захворювань, таких як гіпотиреоз або цукровий діабет, що безпосередньо пов'язані з ожирінням. Розвиток ендокринного ожиріння обумовлений недостатнім виробленням жиромобілізуючих гормонів: кортикотропіну, тиреотропного гормону, соматотропного гормону, тироксину та трийодтироніну, адреналіну, глюкагону. Внаслідок цього знижується ліполіз і використання жиру з депо на енергетичні потреби. У тварин $з$ ожирінням знижуються процеси окиснення, розвивається компенсаторний гіперінсулінізм, що підсилює перетворення вуглеводів корму в жири (Beaver \& Haug, 2003; Rudas et al., 2005; Nel'son \& Feldmen, 2008).

Найбільш вагомими факторами, що першочергово впливають на концентрацію тиреоїдних гормонів у сироватці крові, є активність їх обміну та транспортування (Scuderi et al., 2018; Ou et al., 2018). Існує тісний зв'язок між обмінами білків та тиреоїних гормонів, оскільки $\mathrm{T}_{4}$ i $\mathrm{T}_{3}$ майже стовідсотково зв'язуються 3 білками. Можна зробити висновок, що всі порушення кон'югації з білками будуть у подальшому впливати на загальну концентрацію вищезазначених гормонів у сироватці крові. Тривалий період напіврозпаду $\mathrm{T}_{4}(10$ 16 годин) також обумовлений високим ступенем його зв'язування 3 білками. До останніх належать тироксинзв'язуючий глобулін, тироксинзв'язуючий преальбумін, альбумін та ліпопротеїн високої щільності (ЛПВЩ) і ЛПВЩ2. Щодо періоду напіврозпаду $\mathrm{T}_{3}$, то він значно менший за попередній і триває близько 6 годин. Для $\mathrm{T}_{3}$ основними транспортними білками $є$ альбумін та тироксинзв'язуючий глобулін. Існує думка, що лише ретельний вимір вільних гормонів забезпечує точну оцінку тиреоїдного статусу, порівняно із загальною концентрацією гормонів (Beaver \& Haug, 2003; Ou et al., 2018; Störchle et al., 2018). Це можна пояснити тим, що лише незв'язаний (вільний) гормон може потрапляти у клітини та зазнавати екскреції.

Оскільки організм це цілісна система, метаболізм тварин в цілому зазнає патологічних змін внаслідок зниження рівня тироксину (Graham et al., 2007; Mooney, 2011; Nel'son \& Feldmen, 2008; Lokes-Krupka, 2014). Зменшення інтенсивності обміну речовин призводить до зменшення оксигенації тканин, чим провокує гіпотермію. Оскільки подібні зміни відбуваються відносно всіх видів обміну речовин, не виключенням стає і обмін ліпідів (зростання в сироватці крові холестеролу, ТГ, фракцій ліпопротеїнів низької та дуже низької густини), що у свою чергу призводить до клінічного прояву - збільшення вгодованості хворих тварин як основи симптому ожиріння (Daminet \& Ferguson, 2003; Zimmermann, 2016; Ou et al., 2018).

Саме тому метою роботи є означення клінічних проявів гіпотиреозу у свійських собак із за нормальної так і за надмірної вгодованості.

\section{Матеріал і методи досліджень}

Дослідження проводили впродовж 2016-2019 років на базі клінік ветеринарної медицини м. Полтава клініки ветеринарної медицини при кафедрі терапії імені професора П. І. Локеса Полтавської державної аграрної академії, "Vet Line", "Vet Comfort" та лабораторії кафедри терапії імені професора П. І. Локеса Полтавської державної аграрної академії..

За час виконання роботи нами було досліджено 11 свійських собак, в яких за комплексного обстеження встановлений діагноз гіпотиреоз. Тварини належали до різних порід, мали різну статеву (6 самиць і 5 самців) і вікову приналежність. За контроль нами були взяті 15 свійських собак без видимих ознак будьякої патології.

Зареєстрованих тварин, які надходили до клінік ветеринарної медицини досліджували за загальною схемою: проводили збір анамнезу, визначали габітус, стан шкірного покриву, видимих слизових оболонок, проводили термометрію, зважування, морфометричні заміри та розрахунки, досліджували функціональний стан органів і систем (Szatmari et al., 2004; Ou et al., 2018).

\section{Результати та їх обговорення}

Нами проведено порівняння порідної схильності собак, які страждають на гіпотиреоз та собак із аліментарним ожирінням. Так нами виявлено, що більшість порід є спільними для тварин за обох патологій. Проте в нашій виборці за гіпотиреозу була відсутня така порода свійського собаки як мопс та безпородні особини, що складали значний відсоток собак з аліментарним ожирінням. 
Результати клінічного стану свійських собак за гіпотиреозу наведені у таблиці 1. Встановлено, що у всіх тварин відмічали пригнічення, слабкість та швидку втомлюваність (100,0 \%).

\section{Таблиця 1}

Клінічні симптоми гіпотиреозу у свійського собаки

\begin{tabular}{lcc}
\hline \multirow{1}{*}{\multicolumn{1}{c}{ Клінічні симптоми }} & \multicolumn{2}{c}{ Хворі собаки, } \\
\cline { 2 - 3 } & тварини & $\%$ \\
\hline Пригнічення & 11 & 100 \\
Слабкість та швидка втомлюваність & 11 & 100 \\
Алопеції & 10 & 90,9 \\
Тьмяність та скуйовдження шерсті & 10 & 90,9 \\
Анемічність слизових оболонок & 9 & 81,8 \\
Задишка підчас фізичного навантаження & 8 & 72,7 \\
Брадикардія & 8 & 72,7 \\
Надмірна вгодованість / ожиріння & 7 & 63,6 \\
Нормальна вгодованість & 4 & 36,4 \\
Гіпотермія & 5 & 45,5 \\
Полідипсія & 5 & 45,5 \\
Хвороби очей (дистрофії рогівки) & 4 & 36,4 \\
\hline
\end{tabular}

ках на тлі тьмяного та скуйовдженого шерстного покриву $(90,9 \%)$. У значної частини тварин спостерігалась анемічність слизових оболонок $(81,8$ \%). Симптом брадикардії та задишки під час фізичного навантаження відмічається у 72,7 \% дослідних тварин, що свідчить про розвиток патологічних змін серцевосудинної системи.

За даними літератури відомо, що за гіпотиреозу в собак часто спостерігається симптом ожиріння (Rudas et al., 2005; Mooney, 2011). За нашими даними ожиріння (надмірну вгодованість) реєстрували у 63,6 \% хворих тварин (рис. 1).

Полідипсія і гіпотермія виявлялися значно рідше у 45,5 \% собак, а дистрофія рогівки - у $36,4 \%$ випадків. Останній клінічний прояв виникав у тварин 3 найтяжчим перебігом патології.

За встановленого діагнозу “гіпотиреоз” у свійських собак нами були виділені дві дослідні групи: 1-а тварини 3 нормальною вгодованістю; 2-a - із клінічним симптомом ожиріння. Критерії оцінки ступеню вгодованості наведені в таблиці 2.

Одним 3 клінічних симптомів, який найчастіше реєструвався, є наявність симетричних алопецій на бо-

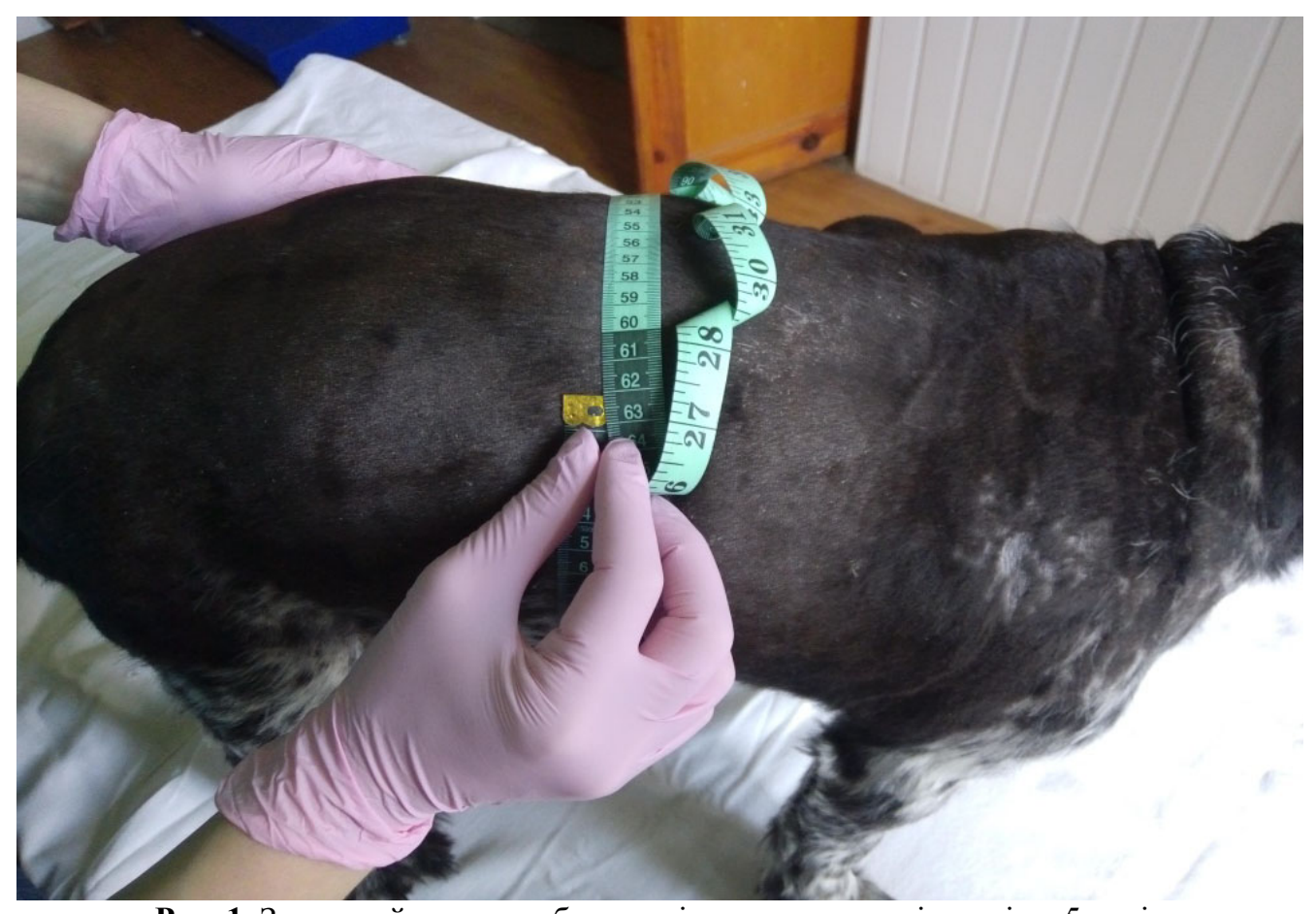

Рис. 1. Загальний вигляд собаки за гіпотиреозу, спанієль, вік - 5 років

Таблиця 2

Критерії оцінки ступеню вгодованості свійського собаки, хворого на гіпотиреоз, $\mathrm{M} \pm \mathrm{m}$

\begin{tabular}{lccrr}
\hline \multicolumn{1}{c}{ Критерій оцінки } & Клінічно здорові & Собаки з аліментарним & Гіпотиреоз, 1-a & Гіпотиреоз, 2-a \\
собаки, $\mathrm{n}=15$ & ожирінням, $\mathrm{n}=30$ & група, $\mathrm{n}=4$ & \multicolumn{1}{c}{ група, $\mathrm{n}=7$} \\
\hline Вміст жирової тканини в організмі, \% & $26,8 \pm 0,38$ & $41,7 \pm 0,75^{* * *}$ & $21,8 \pm 1,38$ & $45,1 \pm 1,70^{* * *}$ \\
Бальна система оцінювання & $2,9 \pm 0,06$ & $4,9 \pm 0,06^{* * *}$ & $2,5 \pm 0,29$ & $4,7 \pm 0,18^{* * *}$ \\
\hline
\end{tabular}

Примітка: *** - $\mathrm{P} \leq 0,001$ порівняно 3 клінічно здоровими собаками

Базуючись на даних таблиці можна відмітити значне зростання вмісту жирової тканини у собак за гіпо- тиреозу 2-ї дослідної групи (45,1 \pm 1,70 \%), що свідчить на наявність ендокринного ожиріння, що підтве- 
рджується візуальною оцінкою вгодованості $(4,7 \pm 0,18$ балів).

\section{Висновки}

Внаслідок захворювання на гіпотиреоз у тварин недостатньо виробляються гормони щитоподібної залози. Останні відіграють важливу роль у регулюванні обміну речовин в організмі. За їх дефіциту обмін речовин в організмі тварин сповільнюється i, в результаті, існує ризик розвитку ожиріння. За нашими дослідженнями встановлено у більшості тварин дослідної групи (63,6 \%) надмірну вгодованість, решта кількість тварин залишалась у межах нормальної вгодованості. Основним клінічним проявом $є$ дерматологічні порушення, а саме алопеції на тлі тьмяного та скуйовдженого шерстного покриву (90,9%). У значної частини тварин спостерігалась анемічність слизових оболонок (81,8 \%). Симптом брадикардії та задишки під час фізичного навантаження відмічається у 72,7 \% дослідних тварин, що свідчить про розвиток патологічних змін серцево-судинної системи. У близько половини тварин реєстрували полідипсію та гіпотермію $(45,5 \%)$.

Перспективи подальших досліджень. У подальших дослідженнях нами буде проведений порівняльний аналіз функціональних та структурних змін внутрішніх органів у свійських собак за ендокринного ожиріння. Важливим є означення диференційної характеристики від аліментарного ожиріння тваринкомпанйонів.

\section{References}

Beaver, B. V., \& Haug, L. I. (2003). Canine behaviors associated with hypothyroidism. J Am Anim Hosp Assoc, 39(5), 431-437. doi: 10.5326/0390431.

Daminet, S., \& Ferguson, D. C. (2003). Influence of drugs on thyroid function in dogs. J Vet Intern Med, 17, 463-472. URL: https://onlinelibrary.wiley.com/ doi/pdf/10.1111/j.1939-1676.2003.tb02467.x.

Graham, P. A., Refsal, K. R., \& Nachreiner, R. F. (2007). Etiopathologic findings of canine hypothyroidism. Vet Clin North Am Small AnimPract, 37(4), 617-631. doi: 10.1016/j.cvsm.2007.05.002.
Lokes-Krupka, T. P. (2014). Aktyvnist fermentiv syrovatky krovi za hepatolipidozu sviyskykh kotiv u protsesi likuvannya. Naukovyy visnyk LNUVMBT im. S. Z. Gzhytskoho, 16, 2(59), 194-198 (in Ukrainian).

Mooney, C. (2011). Canine hypothyroidism: A review of aetiology and diagnosis. New Zealand Veterinary Journal, 59(3), 105-114. doi: 10.1080/00480169.2011. 563729.

Nel'son, R., \& Feldmen, E. (2008). Endokrinologiya i reproduktsiya sobak i koshek. Sofion, 1256 (in Russian).

Ou, X. H., Zhu, C. C., \& Sun, S. C. (2018). Effects of obesity and diabetes on the epigenetic modification of mammalian gametes. Journal of Cellular Physiology, 234(6), 7847-7855. doi: 10.1002/jcp.27847.

Rudas, P., Rónai, Z. S., \& Bartha, T. (2005). Thyroid hormone metabolism in the brain of domestic animals. Domest Anim Endocrinol, 29(1), 88-96. doi: 10.1016/j.domaniend.2005.02.032.

Scuderi, M. A., Ribeiro Petito, M., Unniappan, S., Waldner, C., Mehain, S., McMillian, C. J., \& Snead, E. C. (2018). Safety and efficacy assessment of a GLP-1 mimetic: insulin glargine combination for treatment of feline diabetes mellitus. Domest Anim Endocrinol, 65, 80-89. doi: 10.1016/j.domaniend.2018.04.003.

Shiel, R. E., Acke, E., Puggioni, A., Cassidy, J. P., \& Mooney, C. T. (2007) Tertiary hypothyroidism in a dog. Irish Veterinary Journal, 60(2), 88-93. doi: 10.1186\%2F2046-0481-60-2-88.

Störchle, P., Müller, W., Sengeis, M., Lackner, S., Holasek, S., \& Fürhapter-Rieger, A. (2018). Measurement of mean subcutaneous fat thickness: eight standardised ultrasound sites compared to 216 randomly selected sites. Sci Rep, 8, 16268. doi: 10.1038/s41598018-34213-0.

Szatmari, V., Rothuizen, J., \& Voorhout, G. (2004). Standard planes for ultrasonographic examination of the portal system in dogs. Journal of the American Veterinary Medical Association, 224, 713-716. doi: 10.2460/javma.2004.224.713.

Zimmermann, K. A. (2016). Digestive System: Facts, Function \& Diseases. Live Scienc. URL: https://www.livescience.com/22367-digestivesystem.html. 